\title{
En privé \& en public: The Epistolary Preparation of the Dutch Stadtholders
}

\author{
Michaël Green \\ The Danish National Research Foundation's Centre for Privacy Studies, \\ University of Copenhagen, Denmark \\ mgr@teol.ku.dk \\ Lars Cyril Nørgaard \\ The Danish National Research Foundation's Centre for Privacy Studies, \\ University of Copenhagen, Denmark \\ lan@teol.ku.dk \\ Mette Birkedal Bruun \\ The Danish National Research Foundation's Centre for Privacy Studies, \\ University of Copenhagen, Denmark \\ mbb@teol.ku.dk
}

\begin{abstract}
In his educational treatise, the Instruction du prince chrétien (1642), André Rivet, the tutor of the future Willem II (1627-1650), presents his ideal of a virtuous prince well versed in the skills required to govern himself and his subjects. In the educational correspondences surrounding the future Dutch stadtholders we see some of these theoretical principles played out in epistolary practice. Reading the correspondence against the foil of Rivet's treatise brings to the fore a number of characteristics of his ideal prince: the intimate educational nexus between tutor, parents, and pupil; the way in which the prince is taught to navigate the interrelated spheres of self, household, and society; and finally, the ways in which the dichotomy between public and private is at once dissolved and affirmed in the educational molding of an early modern prince.
\end{abstract}




\section{Keywords}

princely education - correspondence - egodocuments - nobility - selfhood - early modern privacy

\section{Prologue}

In 1642, the French Huguenot theologian André Rivet (1572-1651) published his Instruction du prince chrétien. ${ }^{1}$ The work was dedicated to his former pupil, the future Prince of Orange Willem II (1627-1650) who, in 1647, would become Stadtholder of Holland. Rivet introduces his work as a retrospective gathering of insights on a prince's duties and obligations. Offered by the aging tutor to the ascending prince, the Instruction takes the form of a fictional dialogue between the prince (le prince) and his director (le directeur) as well as a meditation on Psalm 101. ${ }^{2}$ The dialogue idealizes the tutor's charge and situates the prince between the household and society. In both spheres, he has to balance his relation to himself against the common good, because his person and course of action are subject to public scrutiny and divine judgement.

If treatises such as Rivet's convey principles and ideals, they reveal little by way of actual pedagogical situations. However, letters exchanged between princely parents, tutors, and pupils bring us somewhat closer to the more practical aspects of their relationships. In this essay, we discuss how young princes of the Orange-Nassau family were taught to become their best princely selves. The work presented draws from interdisciplinary research at the Danish National Research Foundation's Centre for Privacy Studies, which is dedicated to site-based analyses of notions of privacy and the private in the period from 1500 to 1800 . The research team works with two approaches to the early modern sources. One focuses on terminology related to the Latin privatus and derivative words, as well as their meaning and usage as signifiers deployed to organize a given context such as, in casu, Rivet's ideal of the prince "en privé." The other approach hinges on a set of heuristic zones which allow us to map, in a stylized way, the concerns of early modern society. This second approach brings to the fore the negotiations of notions of privacy and the private across

1 André Rivet, Instruction du prince chrestien. Par Dialogues, Entre un jeune Prince, \& son director. Avec une meditation sur Le Voeu de David (Leiden, 1642), "Epistre dedicatoire." On Rivet, see H.J. Honders, Andreas Rivetus als invloedrijk gereformeerd theoloog in Holland's bloeitijd (The Hague, 193o); A.G. Opstal, André Rivet: Een invloedrijk hugenoot aan het hof van Frederik Hendrik (Hardewijk, 1937).

2 Rivet, Instruction du prince chrestien, 456-500. 
these zones; in this case, the zones related to the princely self, his household, and his societal appearance. ${ }^{3}$

The scope of princely selfhood examined in this article straddles firstly its seclusion, which took the form of prayer and studies; secondly, the position of the prince within the nuclear family and in the wider Dutch princely household; and thirdly the princely comportment in society and his stance in public activities such as hunting, socializing, and military command. We shall follow the young prince as he moves towards the educational highpoint of unsupported exposure to a public sphere by showing how the zones of princely existence are defined and theorized, and how the correspondence teaches the prince to navigate them. Detailing the role of tutors, parents, and grandparents, this study draws its examples from letters exchanged by the Orange-Nassau family between roughly 1632 and 1704, read against the foil of Rivet's Instruction. ${ }^{4}$

3 The Centre for Privacy Studies (DNRF 138) is based at the University of Copenhagen and directed by Mette Birkedal Bruun. For the double approach of the center, see Mette Birkedal Bruun, "Privacy in Early Modern Christianity and Beyond: Traces and Approaches," Annali Istituto storico italo-germanico/Jahrbuch des italienisch-deutschen historischen Instituts in Trient 44, no. 2 (2018): 33-54 (46-49) https://doi.org/10.7387/91458. Our present work on the stadtholder correspondences is indebted to Michaël Green's research on princely education, cf. "The Orange-Nassau family at the educational crossroads of the Stadholder's position (1628-1711)," Dutch Crossing: Journal of Low Countries Studies 43, no. 2 (2019): 99-126 https://doi.org/10.1080/03096564.2016.1186925; "Huguenot Impact on the Education of the Dutch Nobility," Review of Social History 17, no. 2 (2018): 255-270 http://dx.doi.org /10.18778/1644-857X.17.03.10; The HuguenotJean Rou (1638-1711): Scholar, Educator, Civil Servant (Paris, 2015), chapter 5; "A Huguenot Education for the Early Modern Nobility," The Huguenot Society Journal 30, no. 1 (2013): 73-92; "Educating Johan Willem Friso of Nassau-Dietz (16871711): Huguenot Tutorship at the Court of the Frisian Stadtholders," Virtus-Yearbook of The History of the Nobility 19 (2012): 103-124.

4 The rich research field of early modern letter writing brings together issues pertaining to linguistics and social history as well as the letter as a literary genre and a material object, cf. Gabriella Del Lungo Camiciotti, "Letters and Letter Writing in Early Modern Culture: An Introduction," Journal of Early Modern Studies 3 (2014): 17-35. http://dx.doi.org/10.13128 /JEMS-2279-7149-14163. With the increase in literacy, letter writing spread beyond the nobility, and as Daybell observes, the early modern period saw a surge in "personal writing technologies for correspondence, and the emergence of the letter as an increasingly "private" form - a "technology of the self" —utilized for a broadening range of purposes, emotive and affective, spiritual and imaginative, clandestine and covert"; James Daybell, The Material Letter in Early Modern England: Manuscripts Letters and the Culture and Practices of Letter-Writing, 1512-1635 (London, 2012), 233. This also holds true for Dutch letter writing, cf. Michael Mascuch, Arianne Baggerman, and Rudolf Dekker, "Egodocuments and History: A Short Account of the Longue Dureè," The Historian 78 (2016): 11-56; Marijke Van der Wal, Gijsbert Rutten, and Tanja Simons, "Letters as Loot: Confiscated letters filling major gaps in the history of Dutch," in Letter Writing in Late Modern Europe, eds. Mariana Dossena and Gabriella Del Lungo Camiciotti (Amsterdam, 2012), 139-161; Marijke Van der Wal and Gijsbert 
The exchange includes several generations: Frederik Hendrik (1584-1647), Prince of Orange and Stadtholder of Holland, communicates with his son, Willem II. Willem Frederik of Nassau-Dietz (1613-1664) and Albertine Agnes (1634-1696) address their son, Hendrik Casimir II of Nassau-Dietz (1657-1696), who also receives letters from his grandmother, Amalia van Solms-Braunfels (1602-1675). In turn, Hendrik Casimir II and his wife, Henriette Amalia of Anhalt-Dessau (1666-1726), write to their son, Johan Willem Friso of Nassau-Dietz (1687-1711). ${ }^{5}$

\section{The Prince Between Private and Public}

Before turning to these epistolary exchanges, a brief return to the zones charted in the Instruction and navigated by the princely figura is in order. As many other princely mirrors, Rivet's text features a dialogue between the prince and his director which treats issues of relevance to the ideal prince. The margins are crammed with references, and the text thus offers a quasi-catalogue of argumentative repositories for readers, princely and otherwise, which contradicts the seemingly natural ebb and flow of the dialogue and calls attention to its artificial, that is, literary, nature. This intertextual framework lies beyond our focus, but it should be borne in mind.

Rutten, "The Practice of Letter Writing: Skills, Models, and Early Modern Dutch Manuals," Language and History 56, no. 1 (2013): 18-32 https://doi.org/10.1179/1759753613Z.ooooooooo14. Here the impetus of the classical tradition was transferred into vernacular manuals such as Heyman Jacobi, Ghemeene seyndtbrieven, seer profijtelick voor die ouders, meesters en kinderen om te leeren brieven dichten ende oock wel te lesen ende ordentlijck te schrijven (Amsterdam, 1597) and Daniel Mostarts, Vermeerderde Nederduytsche Secretaris Zendtbrief schrijver (Amsterdam, 1649).

5 In 1625, Frederik Hendrik of the senior branch of the Orange-Nassau family and his wife, Amalia van Solms, established their court in The Hague. For this court, see Marika Keblusek and Jori Zijlmans, eds., Princely Display: The Court of Frederik Hendrik of Orange and Amalia van Solms (The Hague, 1997). The junior branch of the Counts of Nassau entertained a small court in Leeuwarden, the capital of the Province of Friesland. The Royal House Archives (RHA) hold the private correspondence of the Orange-Nassau family. The original letters from Frederik Hendrik to Willem II are at the City Archives in Dessau, but the RHA possess handwritten copies of these letters. All references are to the RHA copies. The small number of extant letters to and from females of the Nassau line hinders gender-based comparisons. For insightful studies of epistolary negotiations of family roles in earlier generations of the Nassau line, see Susan Broomhall and Jacqueline Van Gent, "In the Name of the Father: Conceptualizing Pater Familias in the Letters of William the Silent's Children," Renaissance Quarterly 62, no. 4 (2009): 1130-1166 https://doi.org/10.1086/650025; Susan Broomhall and Jacqueline Van Gent, "Corresponding Affections: Emotional Exchange among Siblings in the Nassau Family," Journal of Family History 34, no. 2 (2009): 1-23 https://doi.org/10.1177/0363199008330734. 
The first dialogue outlines a basic vision of princely authority and describes how different forms of principality depend on different historical circumstances. ${ }^{6}$ It explains that the prince is at the same time elevated above others and a servant of God and is thus obliged to secure the common good for his subjects. Next to historical circumstances, the prince shares the general postlapsarian condition. Neither his family name nor the splendor of his kin divests the prince of sin, and the director offers ample evidence to support his claim that the sinful nature of humanity makes even its most influential actors weak in body and spirit. Although a noble bloodline generates a natural disposition for virtue, many princes have committed great misdeeds. ${ }^{7}$ In the second dialogue, Rivet develops this tension between sinfulness and princely elevation. ${ }^{8}$ If the prince is to keep society in a virtuous state, he must offset his natural sinfulness by training himself and making himself virtuous (se evertuer). ${ }^{9}$ Dialogues six to sixteen elaborate on this task. They constitute the main part of the Instruction and deal with justice, prudence, courage, and temperance, respectively. ${ }^{10}$ The argumentative structure thus rehearses the Ciceronian idea of honestas as the embodiment of the four cardinal virtues. ${ }^{11}$

6 Dialogue I: Rivet, Instruction, 1-15.

$7 \quad$ Rivet, Instruction, 9 .

8 Dialogue II: Rivet, Instruction, 15-33.

9 Rivet, Instruction, 31. Virtue in the Instruction signifies an active stance based in the soul and its principal faculties of cognition and the will. To the philosophical background of this theory and its neo-stoic profile, see Matthijs Wieldraaijer, "Onderwijs aan het Oranjehof in de 17de eeuw," Holland 41, no. 2 (2009): 80-10o (81-87).

10 Rivet treats justice in Dialogues VI-VIII: Rivet, Instruction, 130-224. Prudence is the topic of Dialogue IX: Rivet, Instruction, 225-254. This reflection on prudency spills over into a discussion of lying in Dialogue x: Rivet, Instruction, 254-285. In the early modern period, the question of political foxery was closely tied to chapter eighteen of Machiavelli's Il Principe (1513/1532), cf. Michael Stolleis, Staat und Staatsräson in der frühen Neuzeit. Studien zur Geschichte des öffentlichen Rechts (Frankfurt am Main, 199o), 21-36. Courage is treated in Dialogue XI: Rivet, Instruction, 285-321. Like Dialogue X on lying, which is a kind of afterthought to Dialogue IX and its elaboration of prudency, Dialogue XI on courage is followed by discussions of princely liberty in Dialogues XII-XIII: Rivet, Instruction, 321-368. Finally, Rivet discusses temperance in Dialogues XIV-XVI: Rivet, Instruction, 368-437. The latter two dialogues engage with bodily pleasures of, e.g., eating and sexual adventures.

11 This is the conclusion of Wieldraaijer who, however, sees "clemence," "constance," and "liberalité" as separate themes in Rivet's treatise; Wieldraaijer, "Onderwijs aan het Oranjehof in de 17 de eeuw," 84 . Scrutiny reveals that the four virtues are the structural core of the work, and that the discussion of princely clemency is an elaboration of justice; the treatment of lying is an afterthought to the section on prudence; liberty follows from the elaboration of courage; while constancy is described as a form of temperance. 
Before the Instruction reaches this culmination, however, the third dialogue turns to the princely education required to support the training in virtue. ${ }^{12}$ Rivet presents a two-fold educational program which partly develops skills that are necessary to the princely office and partly launches a hermeneutics of the self that prompts the prince to compare himself to past rulers. The prince must be versed in the languages of allies and business partners so as to navigate commercial and political negotiations fluently. Latin remains key, and Latin studies come with the added benefit of giving access to important works from Antiquity in the original. Historical works are crucial princely mirrors which allow for the contemplation of the deeds of past princes, be they virtuous or sinful..$^{13}$ Cosmography and cartography are useful at war and in peacetime. Dialectics enable the prince to distinguish between truth and falsehood, to regulate what is confused, and to underpin his opinions with good arguments. Finally, dialectics is helpful when it comes to "the manner of leading the good life, whether in regard to oneself, to one's domestic life or in the civic life [vie civile]."14 The art of discretion must finally inform his rhetorical education: the prince need not wax eloquent on figures and tropes, but must be able to write and deliver a speech. ${ }^{15}$ While the encouragement to model himself on past rulers introduces a contemplative element, the prince is clearly not to withdraw from the world in order to become virtuous. Knowledge should not be pursued for its own sake.

The last part of the educational framework turns to ethics, economics, and politics. The prince may study general rules in books, but should rely, above all, on his tutor. Casting political reasoning as a diabolic enterprise that upsets divine order, the tutor prepares for the dialogue on religion as the source of moral guidance. ${ }^{16}$ The prince must constantly remind himself that his authority depends on divine will, both as a service to God and as an insight into the divine. ${ }^{17}$ He gains an understanding of God's will through avidly reading the Bible, ideally two chapters a day, and through a constant focus on Christ as the key source of true knowledge of God. ${ }^{18}$ In accordance with this biblical

\footnotetext{
12 Dialogue III: Rivet, Instruction, 33-53.

13 Dialogue III: Rivet, Instruction, 44.

14 Dialogue III: Rivet, Instruction, 47-49.

15 Dialogue III: Rivet, Instruction, 40.

16 Dialogue IV: Rivet, Instruction, 53-102 (51).

17 Dialogue IV: Rivet, Instruction, 56.

18 He therefore need not model himself on, e.g., Alfonso x of Castile (1221-1284), who, according to the director, read the entire Bible fourteen times, cf. Rivet, Instruction, $60-61 ; 67$.
} 
curriculum, Rivet concludes his Instruction with a meditation on Psalm $101 .^{19}$ It is sufficient here to take as a case in point his reference to the young King David's promise to carry himself according to the duties of a prince "in his household and in his estate, in private and in public" (en sa maison, \& en son estat, en privé \& en public). ${ }^{20}$ What seems at a first glance to be a distinction between private and public is in fact a convergence: the prince must everywhere behave as befits a prince.

Rivet structures the components of this princely behavior in three registers: self, court, and country. ${ }^{21}$ With regard to his own person, the prince must live prudently, study piously, and abstain from impiety. As for his staff and ministers, he must avoid people who are debauched, proud, or scheming. Finally, he must be sure to execute justice in a diligent and exact manner, purging his lands of people who pose a threat to the city of God. Psalm 101 is a common reference in Protestant discourses on princely authority. ${ }^{22}$ Particularly

19 Rivet, Instruction, 456-500.

20 Rivet, Instruction, 457. The key verse is Ps 101:2: "I will walk with integrity of heart within my house" (NRSV). This private register of princely preparation should neither be confused with that of the private person (personne privée) raised to power, whom Rivet contrasts with those born to be princes, nor with the vie privée that he defines as the withdrawn contrast of public affairs, cf. Rivet Instruction, 23, 150. This coincides with a development in the houses of the Dutch nobles that began to have more private, secluded spaces with restricted access to their personae. See Jos Gabriëls, Ineke Huysman, Ton van Kalmthout et al. (eds.), In vriendschap en vertrouwen: Cultuurhistorische essays over confidentialiteit (Hilversum, 2014), in particular the introduction by Tom van Kalmhout. For the dynamics of the princely court, see Jeroen Duindam, "Tussen tafellaken en servet. Het stadhouderlijk hof in dynastiek Europa," Bijdragen en mededelingen voor de geschiedenis der Nederlanden, 124 (2009): 536-558. Michaël Green and Rudolf Dekker discuss the term "privacy" in the Dutch context in the forthcoming article "Dutch Egodocuments and Privacy in the Early Modern Period."

21 Further research might illuminate the extent to which these ideals accord with the civic ideal propagated in public Reformed education, cf. Stefan Ehrenpreis, "Reformed Education in Early Modern Europe: A Survey," Nederlands archief voor kerkgeschiedenis/ Dutch Review of Church History 85 (2005): 39-51.

22 In the Luther Bible, Ps 101 was entitled “Davids Regentenspiegel," and Luther's 1534-1535 exposition of this psalm details the role of the prince vis-à-vis his people, inspiring a stream of Lutheran princely mirrors based on the psalm. Furthermore, the Reformed theologian Theodore Beza (1519-1605) saw Ps 101 as an apt reflection of proper princely behavior. See, for the Lutheran tradition, Sara Kipfer, Der bedrohte David: Eine exegetische und rezeptionsgeschichtliche Studie zu 1Sam 16-1Kön 2 (Berlin, 2015), 323-330; for Beza, Edward A. Gosselin, "David in Tempore Belli: Beza's David in the Service of the Huguenots," The Sixteenth Century Journal, 7, no. 2 (1976): 31-54 (47-48) https://doi .org/10.2307/2539558; see also the description of Beza's admonition of Condé by way of Ps 101 in Scott M. Manetsch, Theodore Beza and the Quest for Peace in France: 1572-1598 (Leiden, 2000), 98. Ps 101 has the additional attraction for princely supervisors that it 
important in our context is the meditation on this psalm published in 1594 by the Huguenot theologian Philippe Duplessis-Mornay (1549-1623), who had links both to the house of Orange-Nassau and to Rivet. ${ }^{23}$ Duplessis-Mornay states that the psalm expresses David's decision to become a good prince by first endeavoring to become "a good man, by regulating his person and his private life" (vie privée). ${ }^{24}$ Rivet follows Duplessis-Mornay in distinguishing the work on the self from the concern with the household or court and subsuming both under the general notion of a spotless life (via immaculata, Ps. 101:6). Indeed, he seems even more concerned with the ideally seamless transition between the prince at home and the prince in public. He thus explains that since God tests the mind and the heart (cf. Ps. 7:10), the prince must strive to be pure of heart "everywhere, in public and in private" (par tout, en public \& en particulier). Rivet latches on to the biblical wording "au millieu de ma maison" (in the midst of my house), explaining that the house of a prince is public, and nothing within it is secret. ${ }^{25}$ In this idealized notion of the prince's development, the ongoing work on virtue and the turn to the divine will prompt him to live, in public and in private, as if he were constantly watched by the world, because he is everywhere watched by God. ${ }^{26}$ The princely education seeks to prepare him for this surveillance, with the surveillance of tutor and parents serving as an intermediary stage to which we shall now turn.

underlines the importance of wise counsellors, Véronique Ferrer, "Apprendre à estre Roi': la leçon Politique des psaumes dans les méditations d'Aubigné et de Duplessis-Mornay," Nouvelle Revue du XVI' Siècle 22, no. 2 (2004): 95-109 (102-104).

23 Duplessis-Mornay had been in the service of the Huguenot commander Gaspard de Coligny and corresponded with his daughter, wife of Willem I of Orange (The Silent), Louise de Coligny (1555-1620), Willem II's grandmother on, for example, the education of Frederik Hendrik (see below). The inventory of the Orange-Nassau library compiled in the late seventeenth century refers to a "Meditation sur le 101 ${ }^{e}$. Pseaume. Imprime 1584," see A.D. Renting, J.T.C. Renting Kuijpers, and Anna Sophia Korteweg, The Seventeenth Century Orange-Nassau Library: The Catalogue Compiled by Anthonie Smets in 1686, the 1749 Auction Catalogue, and Other Contemporary Sources (Leiden, 1993), 28o. The bond between Duplessis-Mornay and the house of Orange invites the speculation that the entry concerns Duplessis-Mornay's work, mistakenly dated 1584 instead of 1594. Philippe Duplessis-Mornay, Méditation sur le Psalme Cent-Un, ed. Pascale Blum-Cuny (Paris, 2004), 195 .

25 Rivet, Instruction, 470, echoing Erasmus, Institutio principis christiani 1, 38.

26 Rivet, Instruction, 470. 


\section{Huguenot Education}

Rivet's employment as tutor to the future Prince of Orange formed part of a general trend in early modern Europe. The French Huguenot scholars personified a unique combination of Protestant conviction and a widely recognized intellectual prowess with their native French language. ${ }^{27}$ The Huguenot pedagogical influence on Dutch princes took hold when Louise de Coligny, fourth wife of Willem I of Orange (1533-1584) and mother of Frederik Hendrik, sought educational advice from Philippe Duplessis-Mornay, and Frederik Hendrik followed this trend when he had his son, the later Willem II, brought up in Huguenot traditions under Rivet's watchful eye. ${ }^{28}$

The primary task of the stadtholders in the United Provinces was to command the military, but they also acted as defenders of the Reformed faith and, as the highest nobility in the country, they were expected to demonstrate all aspects of courtly decorum. The princely education targeted this triple end. Courtly civility included the mastery of both written and spoken French. ${ }^{29}$ The Orange and Nassau courts in The Hague and Leeuwarden shared the general European penchant for French as a mark of status for the nobility and the

27 See for example: Green, "The Orange-Nassau family"; Green, Huguenot Jean Rou, chapter 5.

28 On the Orange-Nassau family, see Nicolaas Japikse, De Geschiedenis van het Huis van Oranje-Nassau, 2 vols. (The Hague, 1938); Herbert H. Rowen, The Princes of Orange: The Stadholders in the Dutch Republic (Cambridge, 1988). Duplessis-Mornay authored an instruction to Louise de Coligny regarding the upbringing of Frederik Hendrik, Willem's father: Advis sur l'institution d'ung enfant que l'on veult nourrir aulx lettres; Mémoires et correspondence, vol. 5 (Geneva, 1969; repr. of the edition of 1824-1825), 65-71. If she took the advice to heart, Frederik Hendrik was subject to a somewhat more comprehensive curriculum than his son. On Duplessis-Mornay's idea regarding princely education, see Myriam Yardeni, "Education, institution et instruction chez les Duplessis-Mornay," in Minorités et mentalités religieuses en Europe moderne: L'exemple des Huguenots, ed. Michaël Green (Paris, 2018 [1999]), 103-115; see also Yardeni, "Protestantisme et utopie les écrits politiques et théologiques de Philippe Duplessis-Mornay," in Minorités et mentalités religieuses en Europe moderne, ed. Michaël Green (Paris, 2018), 101-116.

29 On the importance of the French language and culture in the United Provinces, see: Willem Frijhoff, "Verfransing? Franse taal en Nederlandse cultuur tot in de revolutietijd," Bijdragen en mededelingen betreffende de geschiedenis der Nederlanden 104, no. 4 (1989): 592-6o9; Willem Frijhoff and Marijke Spies, Dutch Culture in a European Perspective: 1650, Hard-Won Unity (Houndmills, New York, 2004), 233-235; Green, "A Huguenot Education for the Early Modern Nobility"; Kornelis Jacobus Riemens, Esquisse historique de l'enseignement du Français en Hollande du XVI ${ }^{e}$ au XIX $X^{e}$ siècle (Leiden, 1919); Jonathan Israel, The Dutch Republic: Its Greatness, Rise and Fall 1477-1806, 2nd edition (Oxford, 1998), 72-73. French had been prominent in the Dutch court culture long before Dutch independence, see Frits Pieter van Oostrom, Het word van eer: Literatuur ann het Hollandse hof omtreeks 1400 (Amsterdam, 1987). 
bourgeoisie, and as a language for communicating between members of noble families that, in their capacity as vehicles of political, military, and dynastic alliances, were international. ${ }^{30}$

Letters were a crucial pedagogical tool for teaching French. The correspondences show children struggling with and parents overseeing their acquisition of grammar and syntax. Hendrik Casimir II found this particularly challenging and his mother, Albertine Agnes, constantly admonished him to improve his grammar: "I return to you the aforementioned letter [that you sent me]," she wrote, "so that you can note the mistakes you had made and be wary of making them another time." ${ }^{31}$ She even mentions that her son's head-tutor, Jean de Morel, Sieur de Longval, has given up checking his letters because of Hendrik's poor grammar. ${ }^{32}$ Willem II and Johan Willem Friso fared a shade better; perhaps they had a greater aptitude for learning languages, but much depended on the tutors. ${ }^{33}$

Rivet was one of the most prominent Huguenot tutors. He was a renowned theologian, an internationally recognized authority in exegesis, a university professor, and he was the court pastor before becoming head-tutor in 1632 and being charged with the creation and administration of William II's educational program. ${ }^{34}$ While it is nowhere stated in his commission, the correspondence

$30 \quad$ Heinz Schilling, "The Orange Court. The Configuration of the Court in an Old European Republic," in Princes, Patronage, and the Nobility. The Court at the Beginning of the Modern Age c.1450-1650, eds. Ronald Asch and Adolf M. Birke (Oxford, 1991), 441-454. Both Frederik Hendrik's wife Amalia van Solms and Hendrik Casimir's wife Henriette-Amalia of Anhalt-Dessau (1666-1726) were German-born, although the latter had a Dutch parent. On the social and political importance of the princely court in The Hague, see Olaf Mörke, "William III's Stadholderly Court in the Dutch Republic," in Redefining William III: The Impact of the King-Stadholder in International Context, series Politics and Culture in North-Western Europe, 1650-1720, eds. Esther Mijers and David Onnekink (Aldershot, 2007), 227-240.

31 RHA, A25a, letter from Albertine Agnes to Hendrik Casimir II, Lauderen, 19/29 September 1666.

32 RHA, A25a, letter from Albertine Agnes to Hendrik Casimir II, Franeker, n.d. [before 6 June, unknown year].

33 See the surviving correspondence in $\mathrm{RHA}_{\mathrm{H}} \mathrm{A}_{15}, \mathrm{~A}_{27}, \mathrm{~A}_{2} 6 \mathrm{a}$. On the role of the French tutors and educational aspects of the Orange-Nassau childhood correspondence, see: Green, "The Orange-Nassau Family"; Green, "Educating Johan Willem Friso of Nassau-Dietz"; Green, The Huguenot Jean Rou, chapters 4 and 5 .

34 See Jori Zijlmans, "Life at the Hague Court," in Princely Display, 30-45 (31) and Marika Keblusek, "Books at the Stadholder's Court," in Princely Display, 143-152 (145). Rivet was the court tutor with the highest salary, ranked before the tutors in charge of dancing, fencing, mathematics and fortification and riding, Zijlmans, "Life," 31. 
reveals that Rivet was also to teach the young prince French. ${ }^{35}$ For example, Constantijn Huygens (1596-1687), Frederik Hendrik's secretary, informs Rivet that Willem has written a letter in French to his father with numerous errors, which the tutor must quickly rectify. ${ }^{36}$ Huygens emphasizes, however, that Rivet's corrections should be moderate, so as to leave Willem's original wording and intention visible to his father. ${ }^{37}$ This example shows, at a glance, how letters were circulated among, and were evaluated by, father, secretary, and tutor, but it also indicates that letters were perceived as a reflection of character and assessed as such. Alongside letters in French, Willem II also wrote several letters to his father in Dutch. ${ }^{38}$ These convey his love for rabbit hunting, billiards, and mathematics. Thus, also when writing in his mother tongue, Willem shows a predilection for activities that, as we shall see, are perfectly fit for scrutiny within the framework of a proper princely education.

\section{Epistolary Zones of Privacy}

The correspondence between pupil, tutor, and parents molds the princely self, and requires in turn that the prince demonstrate that such a self is emerging. It also presents the first-person voices of the conscientious tutor and parents concerned for their offspring. The educational correspondence thus lends itself to a study informed by the research regarding the evidence conveyed by egodocuments.

35 The commission is located in: RHA, A15, v-1, "Commissie door Frederik Hendrik in 1632 gegeven aan Andre Rivet, dr in de theologie, hoogleeraar te Leiden, voor opleiding van den jongen Prince Willem II, 12 Feb. 1632." For an analysis of the appointment, see: Green, "The Orange-Nassau family," 106-107.

36 Circulation of Knowledge and Learned Practices in the 17th-century Dutch Republic, online edition, accessed on 3 July 2019, http://ckcc.huygens.knaw.nl/epistolarium/letter. html?id=huygoo1/2704. Letter from Constantijn Huygens to André Rivet, The Hague, 9 May 1641.

37 Ibid.

38 For example: RHA, A14, XI A9, letter from Willem II to Frederik Hendrik, n.p., 1636. The six preserved letters in Dutch all date to Willem II's childhood. We do not know whether Rivet understood Dutch: his aptitude for languages might suggest so, but some Huguenot immigrants never mastered the language. For example, the Huguenot philosopher Pierre Bayle never learned the language during this long stay in The Hague, Wiep van Bunge, From Bayle to the Batavian Revolution: Essays on Philosophy in the Eighteenth-century Dutch Republic (Leiden, 2018): 61-62. 
According to Presser's 1950 definition, egodocuments are texts where "an ego intentionally or unintentionally discloses, or hides itself." 39 Thirty years later, Dekker specified that egodocuments are "autobiographies, memoirs, diaries, personal letters and other texts in which an author explicitly writes about his own affairs and feelings." 40 We can define the letters exchanged between pupil, tutor, and parents as personal letters, since they were not intended for the wider public. But, we may ponder, as indeed we shall below, whether they can be considered private. In any case, neither personal nor private letters offer an unmediated attestation of a self. Following Dekker, such letters do not grant unmediated access to the thoughts, feelings, or interests of their authors. ${ }^{41}$ Indeed, documentation pertaining to the self often involves the simulation of experiences that, historically speaking, have no basis in reality, but which remain essential to the act of self-expression. This essential

39 Jacob Presser, "Memoires als geschiedbron," in Winkler Prins Encyclopedie, vol. 8 (Amsterdam, 1958). On the historical background of Presser's use of the term, see also Rudolf Dekker, "Jacques Presser's Heritage: Egodocuments in the Study of History," Memoria y Civilizacion 5 (2002): 13-37 (25); and Kaspar von Greyerz, "Ego-Documents: The Last Word?," German History 28, no. 3 (2010): 273-282 (277-278) https://doi.org/10.1093/ gerhis/ghqo64.

40 Rudolf Dekker, "Egodocuments in the Netherlands from the Sixteenth to the Nineteenth Century," in Envisioning Self and Status. Self-Representation in the Low Countries 1400-1700, ed. Erin Griffey (Hull, 2000), 255 https://doi.org/10.1080/03096564.1989.11783923. The research field has bifurcated into national research and collections. For the Swiss context, see, e.g., Kaspar von Greyerz, "Deutschschweizerische Selbstzeugnisse Deutschschweizerische Selbstzeugnisse (1500-180o) als Quellen der Mentalitätsgeschichte: Ein Forschungsbericht," in Das dargestellte Ich. Studien zu Selbstzeugnissen des späteren Mittelalters und der frühen Neuzeit, eds. Klaus Arnold, Sabine Schmolinsky and Urs M. Zahnd (Bochum, 1999), 147-163: for the German, e.g., Winfried Schultze, "Ego-dokumente: Annäherung an der Menschen in der Geschichte? Vorüberlegungen für die Tagung EGO-Dokumente," in Ego-Dokumente. Annärung an den Menschen in der Geschichte, ed. Winfried Schultze (Berlin, 1996), 11-30; for the French, e.g., Daniel Fabre, Écritures ordinaires (Paris, 1993); Jean-Pierre Bardet and François-Joseph Ruggiu, eds., 'Car c'est moi que je pein.' Écritures de soi: Individu et liens sociaux en Europe du Moyen Âge à 1914 (Toulouse, 2015); Michel Cassan, Jean-Pierre Bardet, and François-Joseph Ruggiu, eds., Les Écrits du for privé en France de la fin du Moyen Âge à 1914 (Paris, 2015); Sylvie Mouysset, Papiers de famille. Introduction à l'étude des livres de raison (Rennes, 2007); see also Philippe Lejeune's pioneering work Le pacte autobiographique (Paris, 1975).

41 Rudolf Dekker, Ruud Lindeman, and Yvonne Scherf, "Verstopte bronnen: Egodocumenten van Noord-Nederlanders uit de $16^{\text {de }}$ tot $18^{\text {de }}$ eeuw," Nederlandsch archievenblad: Orgaan van de Vereniging van archivarissen in Nederland 86, no. 2-3 (1982): 226-234; Rudolf Dekker, "Ego-documents in the Netherlands 1500-1814," in Dutch Crossing: A Journal of Low Countries Studies 39 (1989): 61-71; Rudolf Dekker, "Introduction," in Egodocuments and History: Autobiographical Writings in its Social Context since the Middle Ages, ed. Rudolf Dekker (Hilversum, 2002), 7-20. 
character hinges on the ways in which these personal testimonials tap into a shared language-use that determines the meaning of even the most private utterances. ${ }^{42}$ Egodocuments thus generally require that we take notions of privacy and the private into critical reconsideration. With regard to princely education, such documents are particularly relevant since, as we saw in Rivet's Instruction, the ability of the prince to govern—and, we may add, expresshimself, determines his ability to govern others.

The educational purpose of the correspondence is supported by an affective register. For example, Frederik Hendrik's letters to the young Willem seem to display a fatherly affection that intensifies proportionately as William became more mature. This seems clear both in the style of address and the reward system deployed. The early letters address the six- or seven-year-old "Wilempie," while the 1640-letters speak to the early teenage "Wilhelm." ${ }^{43}$ The following year, the father addresses the still teenage but now married prince as "My dear child." ${ }^{44}$ This development is accompanied by a promise of paternal reward that evolves in step with the expectation of the prince's ascent in virtue and honnêteté. The young Wilempie is promised a horse, "if you continue to be honnête and to study hard."45 The somewhat more mature Willem is encouraged by the prospect of fatherly love: "I pray to God that he preserves you for many years to come and that he will grant you the grace of becoming as virtuous and wise as I desire it, if you want that I love you." ${ }^{\text {46 }}$ When his wedding approaches

42 See Wittgenstein's argument against private language in Philosophical Investigations, cf. Peter Hacker, Insight and Illusion: Themes in the Philosophy of Wittgenstein (Oxford, 1986).

43 See RHA A15 XI A-1, letter from Frederik Hendrik to Willem II, np., nd., "Willempie, Vous faites fort bien de m'escrire souvent," and RHA A15 XI A-1, letter from Frederik Hendrik to Willem II, "Wilempie, je voudrais que vous auriez este icy," n.p, n.d. Both letters are undated; the transcription suggests the year of 1640, but they are more likely to date from 1632 or 1633 , when Willem was six or seven years old. The spelling oscillates between "Willempie" and "Wilempie." RHA A15 XI A-1, letter from Frederik Hendrik to Willem II, n.p., 12 July 1640 still addresses "Wilempie."

44 RHA A15 XI A-1, letter from Frederik Hendrik to Willem II, n.p., 21 May 1641. It is difficult to determine whether such phrases are formulaic, sincere or both, and whether they are indicative of that strong bond between parents and children in early modern Dutch upbringing practices observed in Jeroen H. Dekker, Het verlangen naar opvoeding. Over de groei van de pedagogische ruimte in Nederland sinds de Gouden Eeuw tot omstreeks 1900 (Amsterdam, 2006); Benjamin Roberts, Through the keyhole: Dutch child-rearing practices in the 17th and 18th centuries, three urban elite families (Hilversum, 1998).

45 See letters A 15 XI A-1 and A 15 Xi A-1.

46 RHA A15 XI A-1, letter from Frederik Hendrik to Willem II, n.p., n.d [ca. 1640], "W. Je suis bien aise d'apprendre que Vous vous portez bien. Je prie Dieu ..." Similar chords are struck in letter RHA A15 XI A-1, letter from Frederik Hendrik to Willem II, n.p., n.d [ca. 1640], "W. Je suis bien aise d'aprandre que Vous portes bien, et de voir ..." (indicating 
in 1641 , however, the said paternal love is stated as a reality: "With all my affection, I will always love you." ${ }^{47}$ Contrary to this, in all of the surviving letters, Hendrik Casimir II is addressed by his mother Albertine Agnes as "mon trescher fils" (my dearest child), ${ }^{48}$ and by his grandmother Amalia van Solms as "mon trescher petitfilz,"49 without developments based on his age. The letters display an understanding of parenthood that is anchored in the social arena of ambition and acclaim. Rather than undermining the affective statements, the avowals related to rewards contribute to the establishment of a strong sense of social selfhood in chiming with the demands mustered in Rivet's Instruction. ${ }^{50}$

The tutor is instrumental in the creation of this social selfhood. As an external voice, he disrupts any assumption of an intimacy that is exclusive to the nuclear family. As a trusted member of the household, he is granted access to, and agency in, a private sphere where crucial dimensions of the virtuous princely self is molded and expressed, preparing him for his public office. Rivet and his colleagues' monitoring of the princely epistolary self-expression and not least their correction of the letters of their young charges create an educational zone where the princely pupil hovers between his position in the family and his position in society-still private in the sense that he is not yet in office. On a terminological level, Rivet's exposition of Ps 101:2 contrasts privé and public, in an echo of the Ciceronian distinction between civic duties and private existence. ${ }^{51}$ The message conveyed by Rivet, however, is that the prince must remain of one virtuous piece: the same in both realms. Thus, the contrast between private and public is at once dissolved and affirmed. The letters aim to shape the prince away from the public gaze, so that he may become fit for his exposure to that gaze, and the educational nexus between tutor, pupil, parents, and secretaries constitutes a private sphere in the sense that this, too, is

that Willem's explicit signs of progress in writing "est le moien à m'obliger à vous aimer de plus en plus").

RHA A15 XI A-1, letter from Frederik Hendrik to Willem II, 9 May 1641. In their examination of the correspondence of the earlier Nassau generation, Broomhall and Van Gent observe that marriages of father or children prompted epistolary renegotiation of status; Broomhall and Van Gent, "In the Name of the Father," 1135.

48 RHA, A26, letter from Albertine Agnes to Hendrik Casimir II, 19/29 July 1667.

49 RHA, A26, letter from Amalia van Solms to Hendrik Casimir II, 24 February 1664.

50 Later pedagogical letter writing became much more structured: Willemijn Ruberg, "Children's Correspondence as a Pedagogical Tool in the Netherlands (1770-1850)," Paedagogica Historica 41, no. 4 (2005): 295-312 https://doi.org/10.1080/oo30923050oo69779; Willemijn Ruberg, "Letter Writing and Elite Identity in the Netherlands, 1770-1850," Scandinavian Journal of History 30, no. 3-4 (2005): 249-258 https://doi.org/10.108o/03468750500272579.

$5^{1} \quad$ For references, see Susan Treggiari, "Home and Forum: Cicero between 'Public' and 'Private,"' Transactions of the American Philological Association 128 (1998), 1-23. 
segregated from the public arena. This private sphere, however, is neither an isolated microcosmos, nor the diametrically opposite of the public sphere: the tutor is a link in intimate familial relations, but his supportive efforts secure a private interaction that abides by public standards. The letters speak to an experience of selfhood that is neither entirely personal nor entirely collective, but rather straddles the two spheres, aiming to shape the entire being of an early modern prince en privé et en public.

\section{Navigating the Zones of Princely Education}

Although parents fussed over the grammatical perfection of their sons' letters, content was key. Expressing and eliciting the right kind of information serves the preparation of the princely ability to scrutinize himself, his court, and the wider society acutely in order to act wisely in all three respects. He is to learn to observe his own inclinations and activities, and thus Frederik Hendrik commands his son Willem II to "inform me about what you do all day - in your studies as well as in your leisure time — and in what you take the greatest pleasure."52 This examen de soi gives the father some access to his son's personal traits and allows him to correct possible deviations. ${ }^{53}$ Willem obliges, reporting that he is engaged in mathematics, but prefers partridge hunting and billiards. ${ }^{54}$ Perhaps this self-reflection is supported by withdrawal; at least on one occasion, Willem II informs his father that he has gone to his room to write to him. ${ }^{55}$ While generally short and rather repetitive, ritually promising better behavior and more diligent studies, sometimes the children's letters show the

52 RHA, A15 XI A-1, letter from Frederik Hendrik to Willem II, n.p., n.d. [possibly 1639 or 1640].

53 Already Erasmus stressed the import of the personal interests of the child in his De pueris instituendis. This idea was also well-known in seventeenth-century educational circles. See Michaël Green, "Bridging the English Channel: Huguenots in the Educational Milieu of the English Upper Class," Paedagogica Historica 54, no. 4 (2018): 389-409 https://doi .org/10.1080/00309230.2017.1409773.

54 RHA, A14 XI A-16, letter from Willem II to Frederik Hendrik, n.p., August 1639. While not quite comparable to mathematics, hunting belongs firmly within the princely curriculum, where also divertissement such as billiards have a place. According to Rivet, just like a bow loses its strength if it is constantly strung, the prince loses his mental and corporeal acuteness without some degree of leisure, and the director allows moderate forms and extents of divertissment, arguing that swimming may prove useful, hunting may be laudable and tennis pleasurable; gambling with dices or cards is, however, out of the question, Dialogue XVII: Rivet, Instruction, 437-455.

RHA, A14, XI A-11, letter from Willem II to Frederik Hendrik, n.p., 1636. 
other side of this intermingling of affection and educational progress. Hendrik Casimir II thus writes to his mother:

I find myself in despair because my writing did not satisfy Your Highness: the next time, I will try to make You more content; not only in this [act of writing] but also in everything else that I will address to You during Your absence. Indeed, I find this [absence] most difficult, because Your Highness is the kindest person to whom I have dedicated all my affections and with whom I desire to be $[\ldots] .^{56}$

The close monitoring of the princely self is above all associated with the cultivation of qualities such as honesty, virtue, and wisdom. ${ }^{57}$ The injunction to become an honnête homme resounds throughout, while the fear of God is also readily invoked. ${ }^{58}$ Such directions take us back to Rivet's ideal that the virtues adding up to honestas ideally inform princely action with regard to the self, the courtly household, and the state. Reading the letters against the foil of the Instruction further reminds us that although we tend to associate honnêteté with the courtly ideal expressed in Castiglione's Il Cortegiano (1528), which was in the stadtholder's library together with the French (1592) and Dutch (1603) translations of Stefano Guazzo's La Civil Conversazione (1574) and other similar works, we should not disregard the link of the term honnêteté to the Ciceronian ideal of the vir honestus who embodies the four cardinal virtues. ${ }^{59}$

$5^{6}$ RHA, A25a 1, letter from Hendrik Casimir II to Albertine Agnes, n.p. [probably Leeuwarden], n.d.

57 RHA A15 Xi A-1, letter from Frederik Hendrik to Willem II, n.p., n.d [c. 1640], "W. Je suis bien aise d'apprendre que Vous vous portez bien. Je prie Dieu ..." Similar chords are struck in letter RHA A15 XI A-1, letter from Frederik Hendrik to Willem II, n.p., n.d [c. 1640], "W. Je suis bien aise d'aprandre que Vous portes bien, et de voir ..."

$5^{8}$ RHA A15 XI A-1, letter from Frederik Hendrik to Willem II, n.p, n.d.

59 Keblusek, "Books," 147. See also the discussion of the ethos of Frederik Hendrik's court in Zijlmans, "Life," 35-38. Cicero, De officiis, 1.4.14-1.5.1 and 1.18.61. Commentators on the seventeenth-century notion of honnêteté tend to see it as a concept that gains ground with Nicolas Faret's L'Honnête homme ou l'Art de plaire á la cour (1630) in the aftermath of Il cortegiano and with late medieval court literature as its antecedent. However, Castiglione was inspired by Cicero in his view of humanitas, Paul Schulten, "Castiglione and Cicero: Wit and Laughter in The Book of the Courtier," in At Whom Are We Laughing?: Humor in Romance Language Literatures, eds. Zenia Sacks DaSilva and Gregory M. Pell (Cambridge, 2014), 161-17o. See also Peter Burke, The Fortunes of the Courtier: The European Reception of Castiglione's Cortegiano (Cambridge, 2007 [1995]), passim. It is not clear whether the Dutch stadtholders received the Ciceronian ideals directly or through intermediaries such as Rivet, whose Instruction has a multitude of references to Cicero, or through, e.g., Erasmus' De civilitate morum puerilium (1530), an important educational propagator 
The prince is not only to scrutinize himself. In accord with Rivet's requirement that the princely education nurture his keen sense of, and behavior within, the household, continuous observation of one's surroundings forms part of the princely education. Albertine Agnes urges Hendrik Casimir II to write to her about everything that occurs around him. ${ }^{60}$ Such reports give her a window into the household, but they also hone Hendrik Casimir's scrutiny of what is for Rivet the intermediary zone between self and society - that is, the household. The parents continually exhort the children to write as often as possible, thus promoting a continuous epistolary exchange and an unbroken chain of reports. The children are less enthusiastic. In each correspondence, we find letters where the child complains that there is nothing to report. Johan Willem Friso's words to his mother are as terse as they are telling: "Your Highness ordered me to write her: nothing has happened this week."61

The third sphere of Rivet's educational system is the princely behavior in society. A key component of this register is military preparation. Paternal reports from the battlefield establish the model.

Willempie, I wish that you had been here yesterday and today to see the entire army take combat: [the battle] went very well; of course, there is no company as good as your company. If you turn yourself into a honnête homme and truly fear God, I hope to see you, one day, commanding the entire cavalry and, thereafter, the entire army. Yet, to get there, it is necessary to really study and pray to God that he bestows upon you all kinds of blessings and as many perfections, as I wish for you. I have something nice to give you when I am back in The Hague. ${ }^{62}$

In this undated letter, the young prince, probably seven or eight years old and already affiliated with a specific company, is attuned to his role as commander of the army. Military theory forms part of his education. Willem reads Caesar's De bello gallico ${ }^{63}$ and engages in mathematics with the explicit goal

of Ciceronian ideals, Zijlmans, "Books," 36. Keblusek mentions that Frederik Hendrik bought some Cicero volumes in 1644, "Books," 145.

6o RHA, A25a, letter from Albertine Agnes to Hendrik Casimir II, The Hague, 19/29 July 1667.

61 RHA, A26a 2, letter from Johan Willem Friso to Henriette Amalia, n.p. [probably Leeuwarden], n.d. [ca. 1700-1701].

62 RHA, A15 XI A-1, letter from Frederik Hendrik to Willem II, n.p. [The Hague?], 13 July (c.1640) [probably 1635]; our italics.

63 RHA, A14 XI A-16, letter from Willem II to Frederik Hendrik, n.p. [The Hague?], August 1639. 
of strengthening his sense of the art of fortification, ${ }^{64}$ but there are also more practical exercises: for example, Willem sends his father a "siege de la ville," perhaps in plan, perhaps in description, and elicits his praise. ${ }^{65}$ Hunting and riding offer physical preparation, and Frederik Hendrik avows his urge to inspect his son's skills in this regard too. ${ }^{66}$

Eventually the prince is considered fit to navigate the world on his own, thereby putting his education to the test. For Willem II, this litmus test was his trip to London in 1641. It is thus of no little consequence that Rivet is able to relate to Frederik Hendrik from London on May 7, 1641 that "By the grace of God, Monseigneur the Prince Willem is in a good condition with regard to his health, his demeanor, and the general judgement," ${ }^{\prime 67}$ just as the father's satisfaction at the reports radiates from the declaration written to his son two weeks later: "My dear child. All your good deeds and all the praise of you have been passed on to me: accordingly, you govern yourself so well during your journey and stay at the court [of Charles I] that it brings me very great delight." ${ }^{\prime 6}$ The educational mission has been accomplished; the prince has proved himself able to govern himself not only en privé, but also en public.

\section{Epilogue}

The educational letters of the future Dutch stadtholders were written by princes, overseen by tutors, read and responded to by parents, and commented on by secretaries. While these letters may be personal in the sense that they convey traits pertaining to the princely person, they do not exactly come across as private. Nonetheless, we argue that there is a private component to these correspondences as evinced by Rivet's Instruction. Such letters were an important vehicle in an education that aimed to equip the prince with all the virtues and skills required to be a good ruler. His virtuous being must be the same at home and in society, ever and everywhere fit to undergo the scrutiny of God and the people. The correspondence offers a glimpse of the molding of this virtuous integrity, highlighting the dynamics that shape the prince in private, that is, away from the public gaze. This private shaping is not in contrast to his public persona. Rather, it paves the way for this persona to enter the world fully-fledged,

64 RHA, A15 XI A-1, letter from Frederik Hendrik to Willem II, n.p. [The Hague?], 12 July 1640, expressing a desire to assess the filial progress upon his return from The Hague.

65 RHA, A 15 XI A-1, letter from Frederik Hendrik to Willem II, n.p., 12 July 1640.

66 RHA, A 15 XI A-1, letter from Frederik Hendrik to Willem II, n.p., 12 July 1640.

67 RHA, A14 XI 27, letter from André Rivet to Frederik Hendrik, [London], 7 May 1641.

68 RHA A 15 XI A-1, letter from Frederik Hendrik to Willem II, Buren, 21 May 1641. 
equally virtuous and possessed of self-control both en privé et en public-two worlds in which the prince must appear to remain the same.

\section{Acknowledgements}

Some excerpts of the Stadtholders' letters have been published in Green's previous publications. The authors thank the Royal House Archives in The Hague for availability of the primary sources used here. All translations of the stadtholderly letters are by Michaël Green and of Rivet's quotes by Lars Cyril Nørgaard. Lars Cyril Nørgaard's research is funded by the Independent Research Fund Denmark. The authors want to thank the anonymous peer-reviewers for their helpful comments and our colleagues at the Danish National Research Foundation's Centre for Privacy Studies for fruitful discussions. 


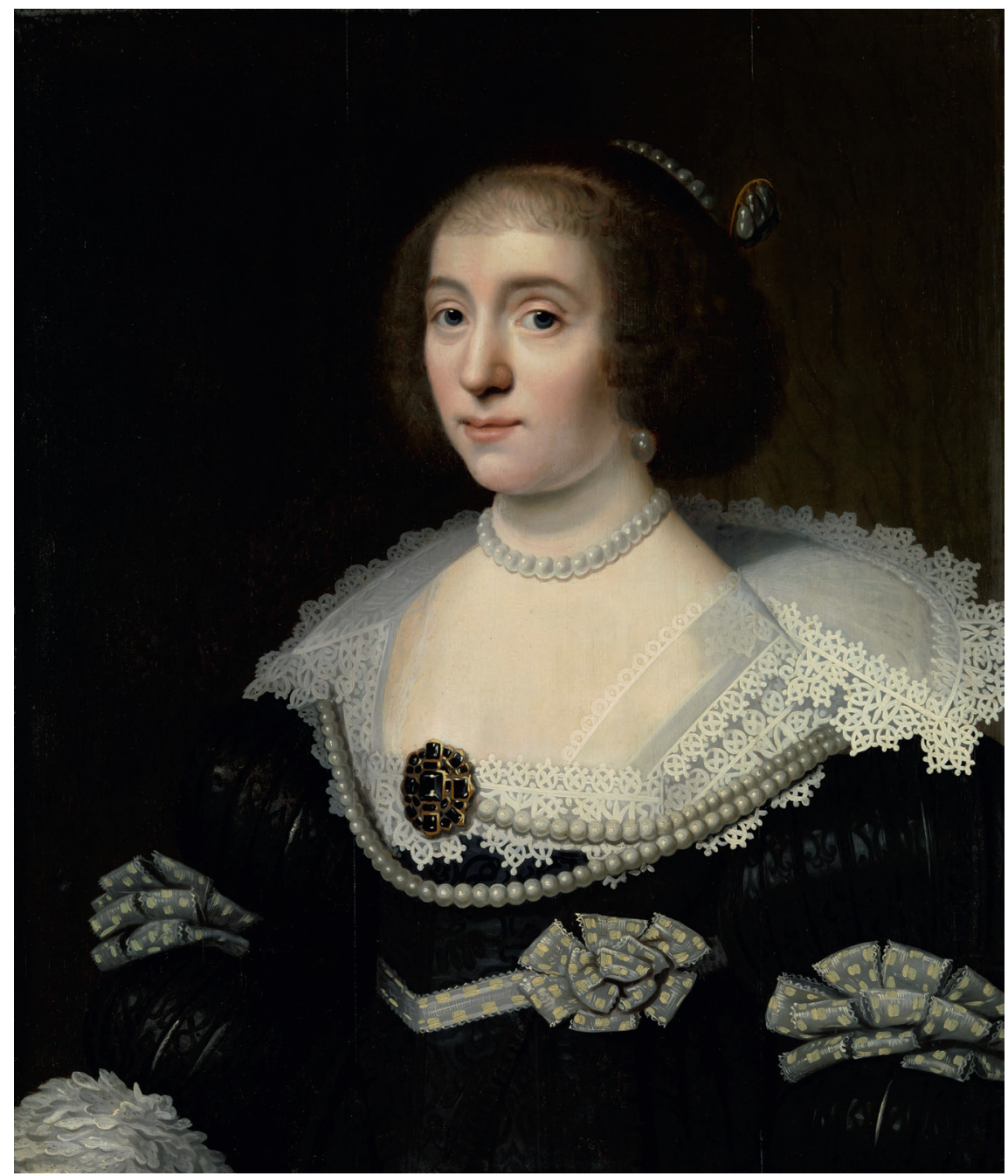

FIGURE 1 Anonymous, copy after Michiel Jansz van Mierevelt, Portrait of Amalia van Solms (1602-1675), oil on panel, circa 1632. Obj. Num. SK-A-572.

(C) RIJKSMUSEUM AMSTERDAM. 


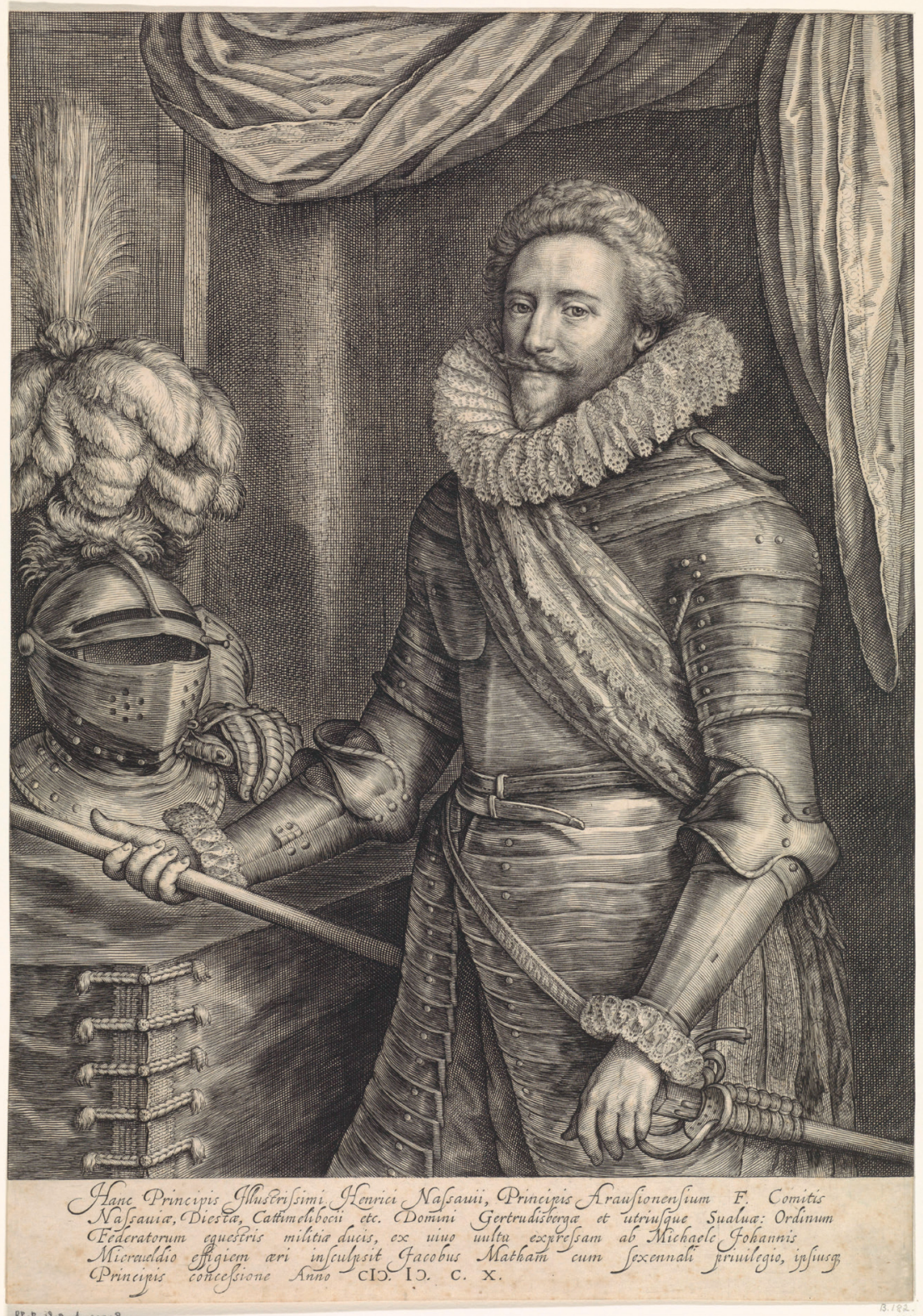

FIGURE 2 Jacob Matham after Michiel Jansz van Mierevelt, Portrait of Frederik Hendrik, Prince of Orange-Nassau, engraving, 1610. Obj. Num. RP-P-1898-A-20708. (C) RIJKSMUSEUM AMSTERDAM. 


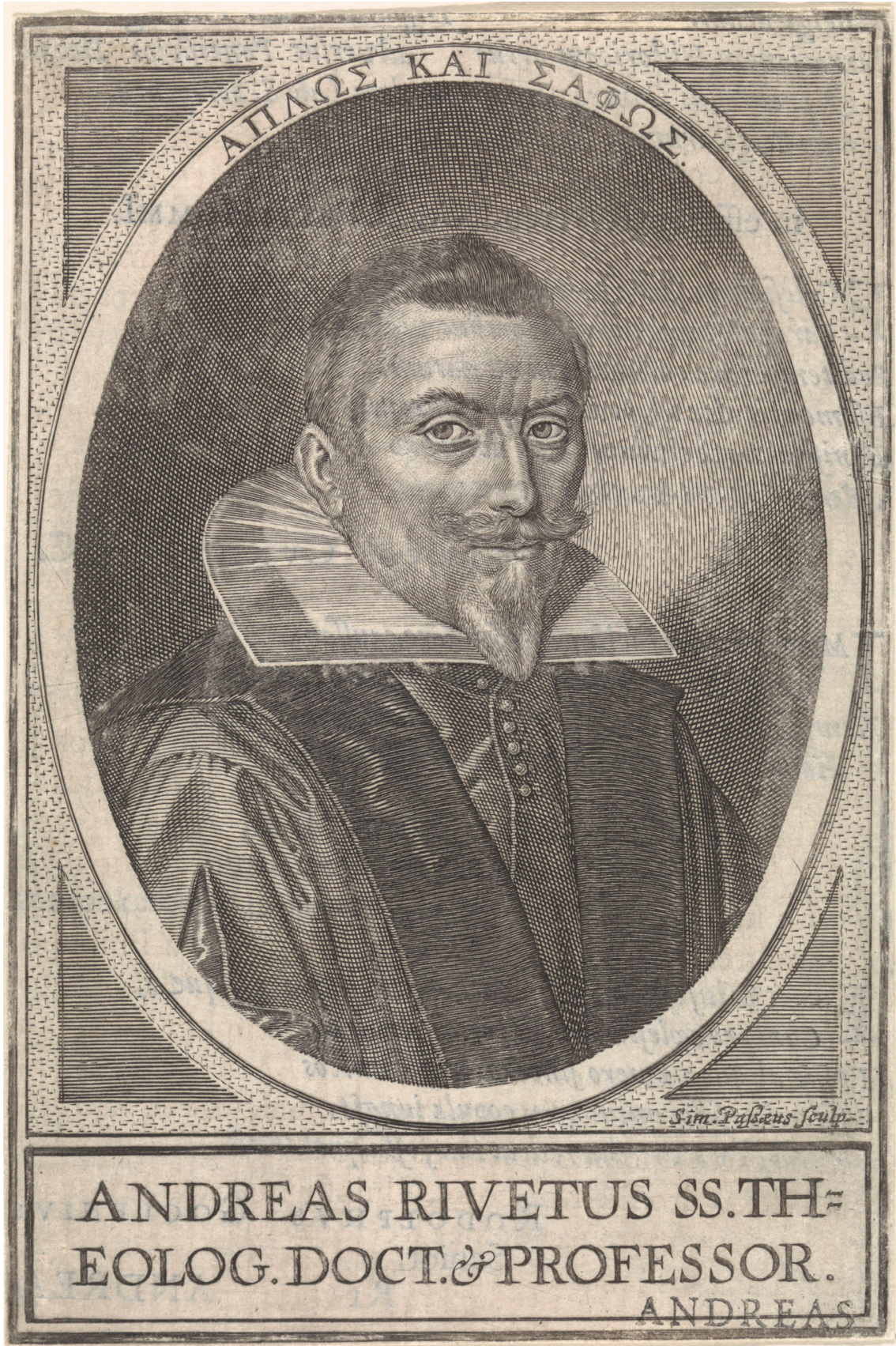

FIgURE 3 Simon van de Passe, Portrait of André Rivet, engraving, 1625.

Obj. Num. RP-P-19o6-2837.

(C) RIJKSMUSEUM AMSTERDAM. 


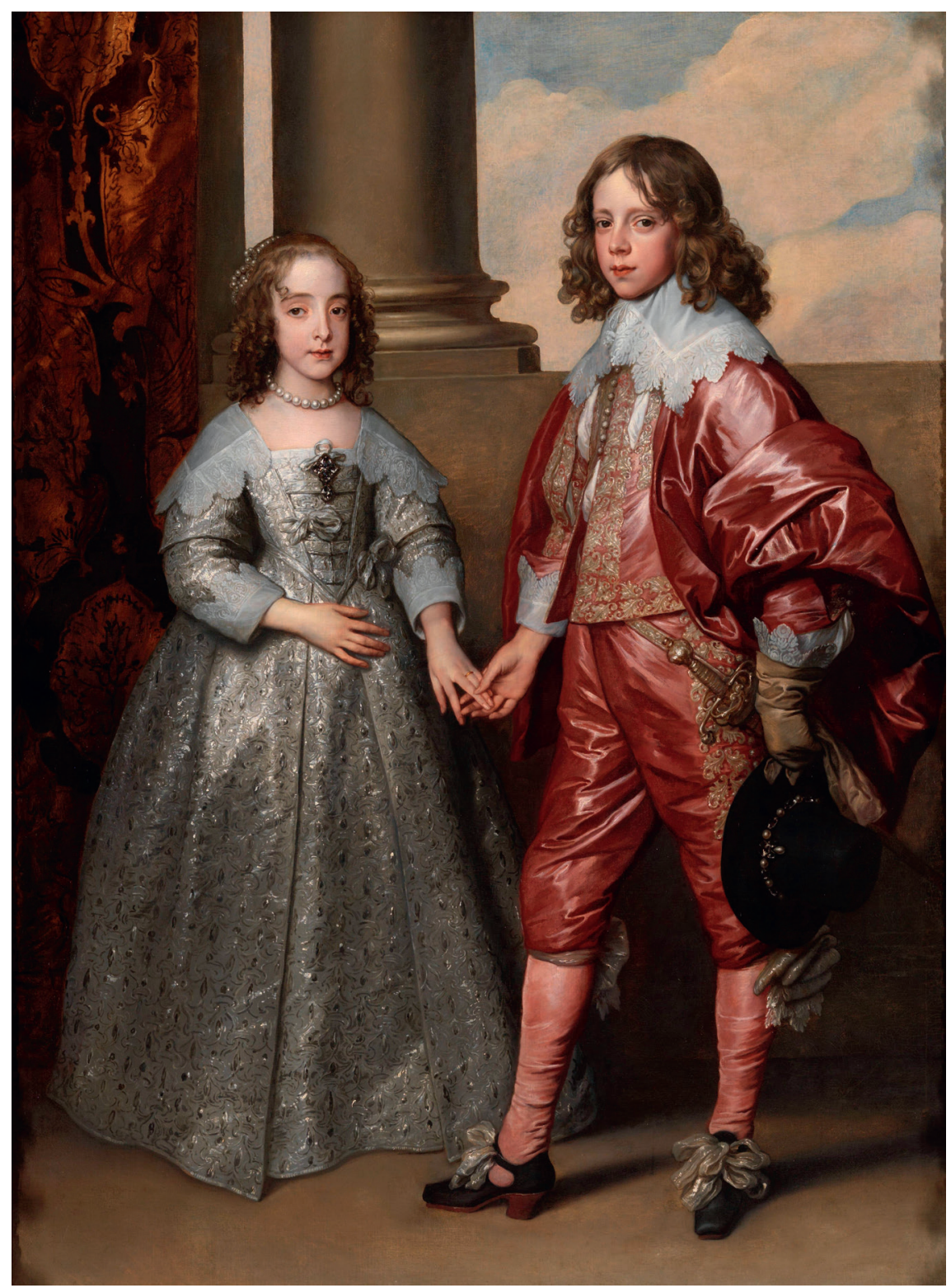

FIGURE 4 Antony van Dyck, William II, Prince of Orange, and his Bride, Mary Stuart, oil on canvas, 1641. Obj. Num. SK-A-102.

(C) RIJKSMUSEUM AMSTERDAM. 


\section{Hendrick Cafimier de II. Gedefigneerde Gouv. van Vriefl. \&c} Moet ftaen pag. 83 . Voor de Befchr. van Vriellant, na fijn Vader.

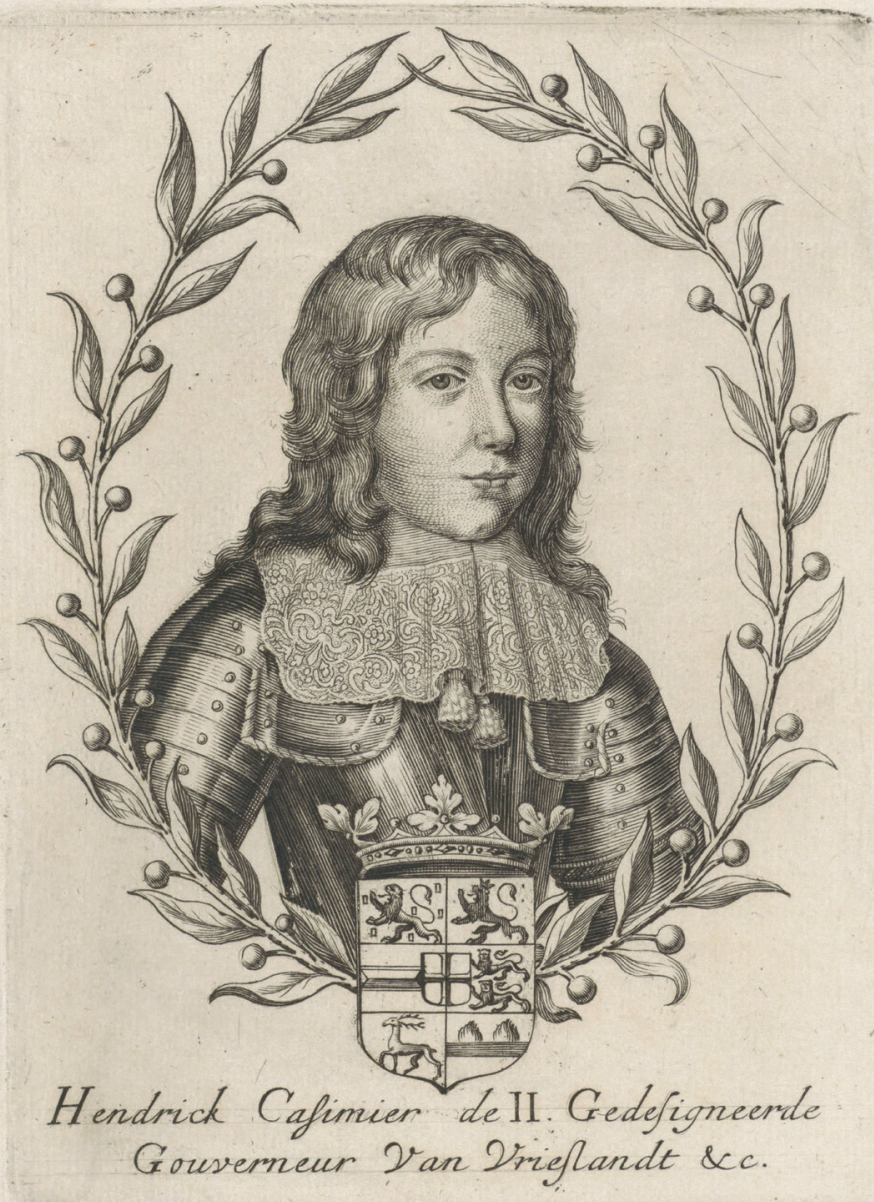

*i:

Chiet op, Nafloufche Spruyt tot heyl der Seven Landen,

Tot cer van uwen ftam, tot nut van uwen ftaet,

Tot uwer vrienden vreugd, tot fchrick van uw' vyanden;

Dit wenfche ick, en mijn wenfch fal meer fijn als maer praet ,

Indien ghy in 't beftier van uw' Stadhouderfchappen,

Verlieft op waren lof, en fchuw voor vleck van blaem

Uw dapp'ren Vader poogt en Grootvaêr nae te ftappen,

En uwen Oom in deugd foo na komt als in nacm.

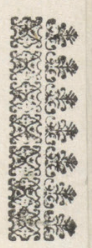

FIgure 5 Levijn van Dijck, Portrait of Hendrik Casimir II, Count of Nassau-Dietz, engraving, 1667. Obj. Num. RP-P-OB-105.o36.

(C) RIJKSMUSEUM AMSTERDAM. 


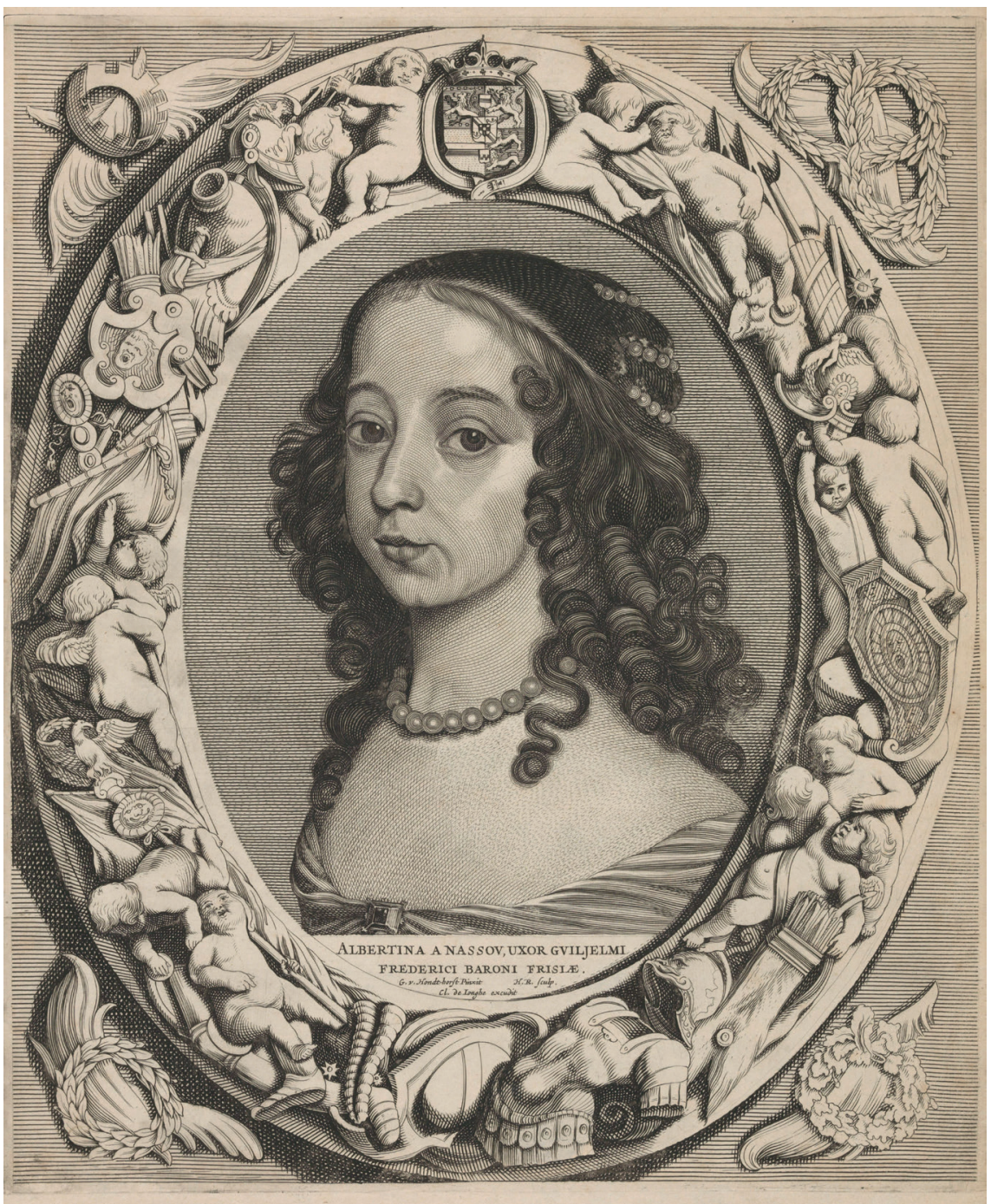

FIGURE 6 Hendrik Rokesz van Dagen, after Cornelis Visscher (II), after Gerard van Honthorst, Portrait of Albertine Agnes, Princess of Orange, engraving, 1649-1677. Obj. Num NG-564-A.

(C) RIJKSMUSEUM AMSTERDAM. 


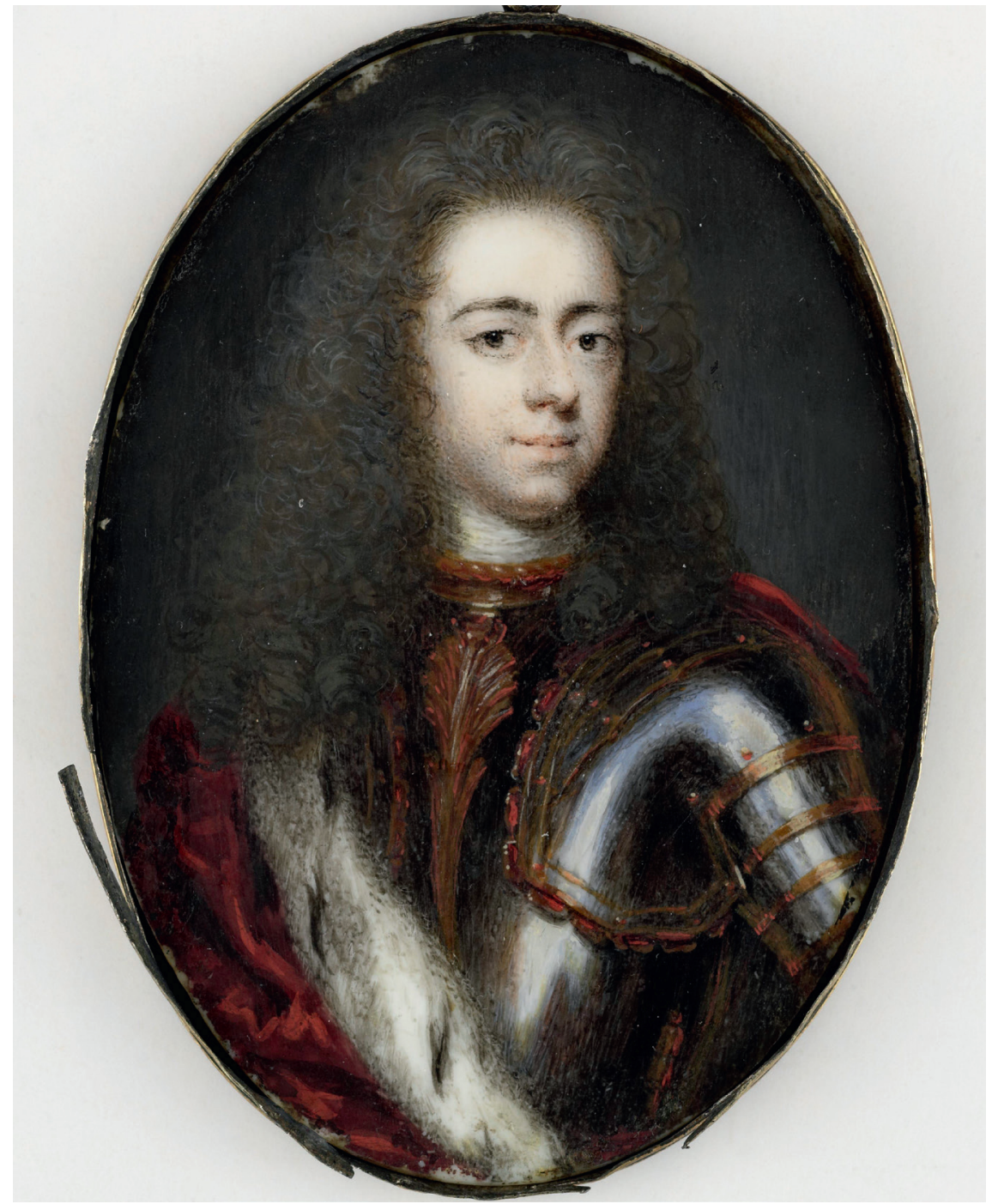

FIGURE 7 Christof Le Blon (attributed to) after Lancelot Volders, Johan Willem Friso (1687-1711), Prince of Orange-Nassau, oil on ivory, ca. 1710. Obj. Num sk-A-444O. (C) RIJKSMUSEUM AMSTERDAM. 


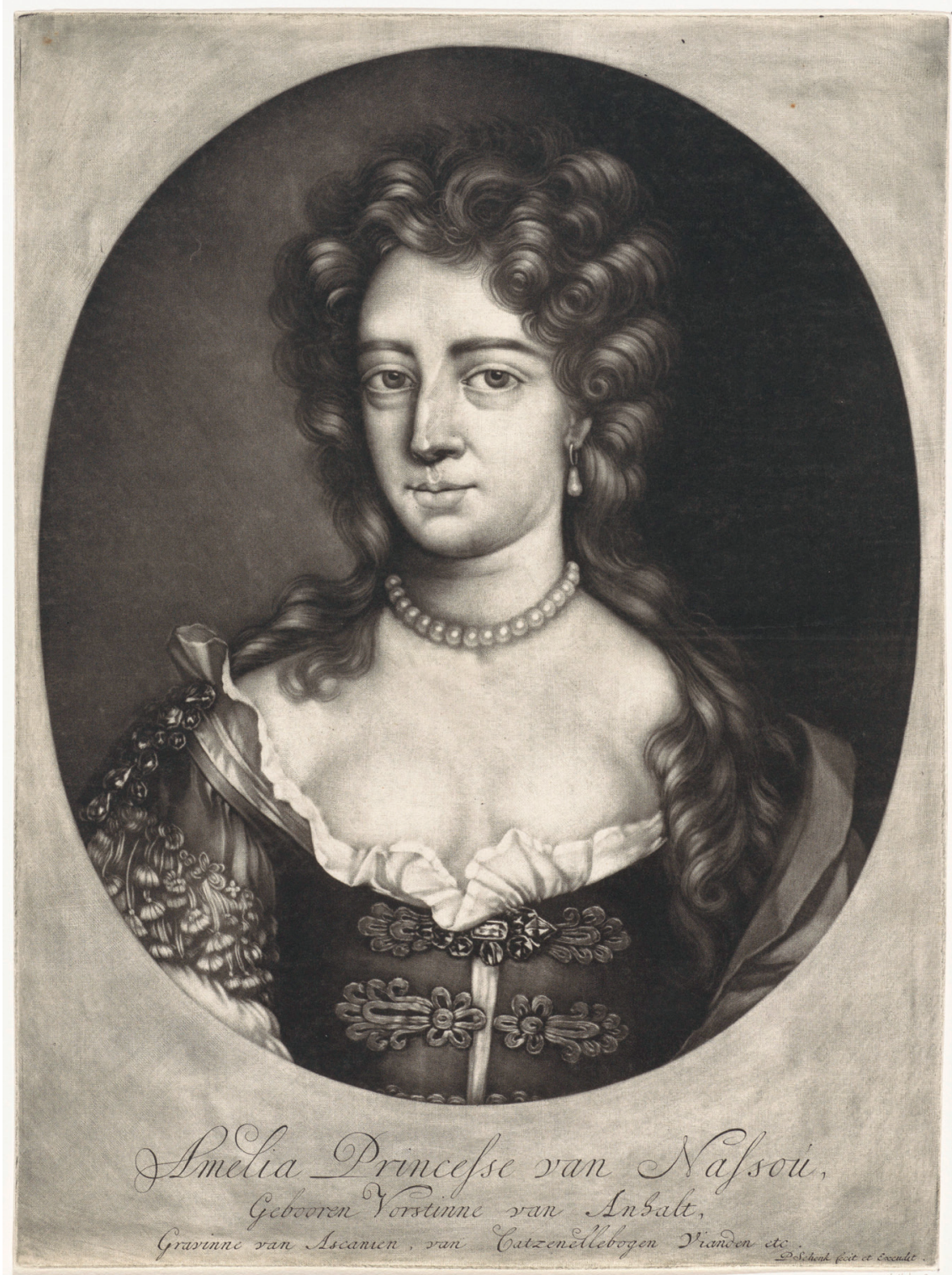

FIGURE 8 Pieter Schenk (I), after Gottfried Kneller, Portrait of Henrietta Amalia, Princess of Anhalt-Dessau, 1670-1713. Obj. Num RP-P-оB-9208.

(C) RIJKSMUSEUM AMSTERDAM. 